\title{
Budaya Struktur Pemerintahan Republik Islam Iran
}

\author{
Zul Karnen \\ Program Studi Sastra Arab, Fakultas Sastra \\ Universitas Al Azhar Indonesia \\ Komplek Masjid Agung Al-Azhar, Jl. Sisingamangaraja, \\ Kebayoran Baru, Jakarta Selatan, 12110 \\ Penulis untuk Korespondensi/Email : zulkarnen@uai.ac.id
}

Abstrak - Kelahiran Republik Islam Iran tidak lepas dari peran Ayatollah Imam Khomeini, pemimpin spiritual ulama, sekaligus pemimpin politik yang sangat dihormati di Iran. Imam Khomeini adalah salah satu tokoh terpenting di balik revolusi Iran dan kelahiran Republik Islam Iran. Karena perannya dalam memimpin revolusi Iran bahwa Imam Khomeini ditunjuk sebagai Pemimpin Revolusi Islam, sebagaimana tercantum dalam konstitusi Iran yang disahkan pada bulan Desember 1979. Salah satu gagasan paling menonjol dalam pemikiran politik Imam Khomeini adalah idenya tentang Wilayatul Faqih (tata kelola faqih) yang pada dasarnya menuntut kepemimpinan pada umumnya, termasuk kepemimpinan politik, harus berada di tangan yang terpercaya. Pemikiran politik Imam Khomeini tentang Wilayatul Faqih yang menjadi bagian terpenting dalam struktur politik Republik Islam Iran adalah menekan imamah yang didefinisikan sebagai kepemimpinan religius dan politis serta dilakukan oleh faqih. Wilayatul faqih merupakan kelanjutan dari doktrin Imamah dalam teori politik Syiah khususnya Shia Imami. Struktur ini bukanlah ide baru dalam pemikiran kalangan Syi'ah. Imam Khomeini yang kemudian mengembangkan dan mempraktikkan wilayatul faqih ke dalam sistem pemerintahan modern Iran. Dalam menerapkan gagasannya, Imam Khomeini berhasil menggabungkan struktur pemerintahan religius dengan institusi demokrasi. Namun, Imam Khomeini memiliki definisi demokrasi yang berbeda dengan demokrasi murni dan demokrasi liberal. Dia mengatakan bahwa kebebasan demokratis harus dibatasi dan kebebasan yang diberikan harus dilakukan dalam batas-batas hukum Islam. Meski demikian dapat dikatakan bahwa konsep Wilayatul faqih merupakan salah satu varian demokrasi. Dalam konsep keseimbangan dan mekanisme penyelarasan (checks and balances) ini harus berjalan, meski lembaga tersebut berada di bawah kewenangan wali faqih. Menurut Imam Khomeini tanpa pengawasan Wilayatul faqih, pemerintah akan lalim. Jika peraturan tersebut tidak sesuai dengan kehendak Tuhan dan jika Presiden dipilih tanpa arahan faqih, peraturan tersebut tidak berlaku. Sistem pemerintahan Republik Islam Iran dapat diklasifikasikan ke dalam sistem demokrasi agama, apapun istilahnya diberikan; baik istilah "Teo-Demokrasi" Maududi, "Theistic Democracy" Moh. Natsir "Islamo-Demokrasi" Nurcholis Madjid, Demokrasi, Islam atau apapun yang mencapnya pada dasarnya sama. Sebagai konsekuensi logis, Implikasi struktur gagasan Khomeini tentang demokrasi Islam adalah model dan bentuk pemerintahan alternatif yang bisa menjadi referensi bagi negara-negara Muslim lainnya di masa depan.

Kata Kunci - Wilayatul Faqih, Implementasi, Sistem, Struktur

Abstract-The birth of the Islamic Republic of Iran can not be separated from the role of Ayatollah Imam Khomeini, a cleric's spiritual leader, as well as a highly respected political leader in Iran. Imam Khomeini was one of the most important figures behind the Iranian revolution and the birth of the Islamic Republic of Iran. Because of its role in leading the Iranian revolution that Imam Khomeini was appointed as Leader (leader) of the Islamic revolution, as listed in the Iranian constitution which was passed in December 1979. One of the most prominent ideas in the political thought of Imam Khomeini was his idea about Wilayatul Faqih (governance of the faqih) which basically calls for leadership in general, including political leadership, should be in trusted hands. Imam Khomeini's political thinking about Wilayatul Faqih who became the most important part in the political 
structure of the Islamic Republic of Iran is putting pressure on the Imamat which is defined as a religious and political leadership as well as carried by the faqih. Wilayatul faqih is a continuation of the doctrine of Imamat in Shi'i political theory in particular Shia Imami. This structure is not a new idea in the thinking among the Shi'a. Imam Khomeini who later develop and practice Wilayatul faqih into Modern Iranian system of government.In applying his ideas, Imam Khomeini succeeded in combining the religious government structure with democratic institutions. However, Imam Khomeini has a different definition of democracy with pure democracy and liberal democracy. He said democratic freedoms should be restricted and the freedom granted shall be exercised within the limits of Islamic law. Nevertheless it can be said that the concept Wilayatul faqih is one variant of democracy. In this concept of balance and alignment mechanisms (checks and balances) must be running, although the institution is located under the authority of guardians faqih. According to Imam Khomeini without the supervision of Wilayatul faqih, the government will be despotic. If the rule is inconsistent with God's will and if the President shall be elected without the direction of a faqih, the rule is not valid. System of government of the Islamic Republic of Iran can be classified into a religious democratic system, whatever the term is given; either the term "Teo-Democracy" Maududi, "Theistic Democracy" Moh. Natsir "Islamo-Democracy" Nurcholis Madjid, Democracy, Islam or anything that labeled him basically the same. As a logical consequence, Implications of the structure of Khomeini's notion of Islamic democracy is a model and an alternative form of government that could be a reference for other Muslim countries in the future.

Keyword - Wilayatul Faqih, Implementation, System, Structure

\section{PENDAHULUAN}

\section{Latar Belakang Masalah}

Ayatullah al-Uzma Ruhullah Sayyid al-Musawi Imam Khomeini adalah seorang teolog Islam pertama yang mengembangkan dan mempraktikkan gagasan pemerintahan Islam di dunia modern. ${ }^{1}$ Ia merupakan salah seorang tokoh yang paling penting di balik terjadinya revolusi Iran dan lahirnya negara Republik Islam Iran. Karena peranannya dalam memimpin revolusi Iran itulah, Imam Khomeini kemudian diangkat sebagai pemimpin revolusi Islam, sebagaimana yang tercantum dalam konstitusi Iran yang disahkan pada 3 Desember $1979 .{ }^{2}$

Salah satu pemikiran revolusioner yang ditawarkan oleh Imam Khomeini adalah gagasannya mengenai struktur pemerintahan Islam wilayatul faqih, ${ }^{3}$

\footnotetext{
${ }^{1}$ Moin, "Ayatullah Khomeini Mencari Kesempurnaan: Teori dan Realitas" dalam Ali Rahnema (ed), Para Perintis Zaman Baru Islam (Bandung: Penerbit Mizan, 1996), hal. 69.

${ }^{2}$ Sihbudi, Biografi Politik Imam Khomeini. (Jakarta :PT Gramedia Pustaka Utama, 1996). Hal 80.

3 Wilayatul faqih adalah pemerintahan oleh faqih, struktur ini merupakan struktur yang ditawarkan oleh Imam Khomeini, yang kemudian dibudayakan dalam struktur pemerintahan Republik Islam Iran, gagasan ini sebenarnya sudah lama ada khususnya oleh para pemikir Islam khususnya di Indonesia melalui MASYUMI (Majlis Syuro Muslimin Indonesia) namun dipopulerkan oleh Imam Khomeini terutama
}

Sekalipun tidak dikenal sebagai seorang teoritikus di bidang filsafat politik, namun Imam Khomeini mampu mempraktikkan gagasan pemerintahan Islam yang menempatkan kaum ulama sebagai pemegang kekuasaan di bidang politik maupun agama. Dalam gagasan ini Khomeini menekankan akan perlunya seorang faqih (ulama) untuk memegang kendali pemerintahan sebagaimana halnya Rasullullah memimpin generasi awal umat Islam. $^{4}$

\section{Penelitian Sebelumnya \\ Keberhasilan Imam Khomeini dalam memimpin revolusi Islam Iran pada tahun 1978-1979 yang mengubah struktur politik dan bentuk negara Iran dari monarki absolut ke bentuk pemerintahan republik Islam, telah merebut beberapa perhatian para pemikir dan pengamat politik. Sejak peristiwa}

semenjak revolusi Iran tahun 1979. Istilah tersebut berarti "perwalian hakim". Ketika hakim Khomeini mulai berkuasa pada 1979 serta menjadi hakim tertinggi untuk seluruh aspek pemerintahan di Iran, Istilah tersebut menjadi jelas bagi dunia Islam sebagai struktur utuh bahwa perwalian semacam ini merupakan sebuah rute menuju ideal yang didambakan kaum Muslim kontemporer, yakni pemerintahan Islam. Lihat Roy P. Mottahedeh, entri "Wilayah al-Faqih" dalam Jhon L Esposito (ed), Ensiklopedi Oxford Dunia Islam Modern Jilid VI, terj. Eva YN (Bandung: Penerbit Mizan, 2001), hlm. 161.

${ }^{4}$ Thaha, "Revolusi Iran dan Imam Khomeini: Wilayat al-Faqih dan Demokrasi", dalam Jurnal Al-Huda (Vol. V, No. 13, 2007), hlm. 47. 
ini cukup banyak kajian-kajian kritis yang dihasilkan yang membahas mengenai, revolusi, gerakan politik, dan pemikiran-pemikiran politik Imam Khomaeni.

Tulisan-tulisan tersebut kebanyakan mengulas mengenai revolusi dan gerakan Islam Syi'ah, seperti buku Iran Pasca Revolusi: Sebuah Reportase Perjalanan yang ditulis oleh Syafiq Basri, sebuah buku karya Riza Sihabudi yang berjudul Dinamika Revolusi Islam Iran: Dari Jatuhnya Syah Hingga Wafatnya Ayatullah Khomeini. 5 Beberapa penulis luar misalnya Hossein Bashiriyeh, yang menulis buku The State and Revolution in Iran 1962-1982, dan Nasir Tamara yang menulis Revolusi Iran. Keempat buku di atas merupakan sebagian dari sekian banyak buku yang membahas mengenai Iran dan situasi politik seputar revolusi.

Kajian yang khusus membahas mengenai Imam Khomeini dan pemikiran politiknya antara lain seperti buku Biografi Imam Khomeini yang ditulis Riza Sihbudi, kemudian Amir Taheri dalam bukunya yang berjudul The Spirit of Allah: Khomeini and The Islamic Revolution, dan buku karya Yamani, Filsafat Politik Islam: Antara alFarabi dan Khomeini, buku ini mengupas riwayat hidup, latar belakang pendidikan, sampai karier politik dan kondisi sosial politik yang terjadi di Iran semasa hidup serta pemikiran politik Imam Khomeini. $^{6}$

Karya-karya yang mengkritik pemikiran Khomeini juga banyak ditulis seperti, buku Menggugat Otoritas dan Tradisi Agama, yang ditulis oleh

\footnotetext{
5 Basri,. Iran Pasca Revolusi, Sebuah Reportase Perjalanan, diterbitkan oleh Pustaka Sinar Harapan di Jakarta, 1987. Dalam bukunya yang merupakan hasil penelitiannya di Iran, Safiq lebih banyak menggambarkan situasi politik yang terjadi di Iran pasca terjadinya revolusi 1979; Riza Sihbudi merupakan peneliti pada puslitbang politik dan kewilayahan LIPI. Juga dikenal sebagai kolomnis masalah-masalah timur tengah di berbagai media masa di Indonesia, selain itu tulisannya banyak tersebar di beberapa jurnal, seperti Ulumul Quran, dan beberapa buku telah ia hasilkan seperti buku yang berjudul Dinamika Revolusi Islam Iran: Dari Jatuhnya Syah Hingga Wafatnya Ayatullah Khomeini. terbitan Pustaka Hidayah.

${ }^{6}$ Sihbudi, Biografi Politik Imam Khomeini (Jakarta: Gramedia Pustaka Utama dan ISMES), 1996; Amir Taheri, The Spirit of Allah: Khomeini and The Islamic Revolution, (London: Hutnehinson), 1985; Yamani, Filsafat Politik Islam: Antara al-Farabi dan Khomeini, (Bandung: Penerbit Mizan), 2002.
}

Abdul Karim Soroush, seorang cendekiawan muslim "liberal" Iran Kontemporer, dalam buku ini Sorrous beranggapan bahwa pemerintahan yang didominasi ulama saat ini kurang memiliki basis teoritis. ${ }^{7}$ Tulisan Abdul Hakim Irfan yang berjudul Nadriyat al-Wilāyat al-Faqih: Dirāsat wa Tahlīl wa Naqd, juga merupakan kajian yang mengkritik pemikiran Khomeini. ${ }^{8}$

Kajian mengenai wilayatul faqih juga menjadi bahasan pokok yang banyak disoroti baik oleh kalangan peneliti luar maupun dalam negeri. Ahmed Vaezi dalam bukunya yang berjudul Syi'ah Islamic Thought, mengkaji secara umum mengenai pemikiran politik Syi'ah, termasuk di dalamnya kajian mengenai pemerintahan Islam, terutama bab kedua yang secara khusus membahas mengenai wilayatul faqih. ${ }^{9}$ Yang menarik dari studi ini adalah pada bagian akhir Vaezi dengan lugas menguraikan dikotomi struktur demokrasi Islam yang dituangkan dalam teori wilayatul faqih dengan interpretasi liberal dari struktur demokrasi yang dianut oleh mayoritas negara-negara Barat.

Studi lain yang khusus membahas mengenai wilayatul faqih, ialah studi yang dilakukan oleh Mehdi Hadavi Teherani dengan judul The Theory of Governance of Jurist (Wilayat al-Faqih) yang menelaah secara ringkas struktur negara dari sisi penafsiran atas fondasi gagasan pemerintahan Islam. ${ }^{10}$ Kajian ini juga mengupas pendapatpendapat hukum dan alasan-alasan teologis dari pemerintahan Islam. Fokus masalah yang dikaji dalam studi ini adalah usaha untuk menjawab atas pertanyaan teologis mengenai pemerintahan agama

\footnotetext{
${ }^{7}$ Soroush, Menggungat Otoritas dan Tradisi Agama, terj Abdullah Ali, (Bandung: Penerbit Mizan), 2002

${ }^{8}$ Irfan, Nadriyat al-Wilāyat al-Faqih: Dirāsat wa Tahlīl wa Naqd, (Darul Imar), 1988.

${ }^{9}$ Vezi merupakan Profesor di ICAS (Islamic College for Advance Studies) London, Inggris. Karyanya berjudul Syi'ah Islamic Thought diterbitkan oleh ICAS (Islamic College for Advance Studies) London, England tahun 2001. Buku ini telah diterjemahkan ke dalam bshasa Indonesia oleh Ali Syahab dengan judul Agama Politik: Nalar Politik Islam, diterbitkan oleh Penerbit Citra, tahun 2006.

10 Teherani merupakan Profesor dari International Center of Islamic Studies (ICIS). Studinya berjudul The Theory of Governance of Jurist (Wilayatul faqih) terbitan ICIS (International Center of Islamic Studies), tahun 2004, yang telah diterjemahkan kedalam Bahasa Indonesia oleh Rudi Mulyono dengan judul Negara Ilahiyah: Suara Tuhan, Suara Rakyat ditrbitkan oleh Penerbit Al-Huda Jakarta, tahun 2005.
} 
secara umum dan pemerintahan Islam secara khusus dalam hal ini wilayatul faqih.

Beberapa karya lain yang membahas mengenai struktur ini antara lain; artikel yang ditulis oleh Mohsen M. Milani, guru besar University of Florida yang berjudul The Transformation of The Velayat-i-Faqih Institution : From Khomeini to Khemenei, tulisan yang dimuat dalam jurnal The Muslim World ini mencoba menganalisis transformasi kekuasaan dari Khomeini sebagai pendiri Republik Islam Iran ke Khamenei yang merupakan murid setia beliau, penilaian ini dari sudut pandang teori wilayatul faqih. Kajian lain yang membahas wilayatul faqih adalah ditulis oleh Ahmad Mousawwi yaitu Teori Wilayatul faqih: Asal Mula dan Penampilannya dalam Literatur Hukum Syi'ah, pada tulisan ini beliau mencoba mengemukakan pendapat-pendapat para fuqaha syi'ah mengenai Wilayatul Faqih dan proses aplikasi teori tersebut dalam pemerintahan Iran juga tulisan peneliti dalam negeri Riza Sihabudi dalam jurnal Ulumul Qur'an, Tinjauan Teoritis dan Praktis atas Struktur Vilayat-i-Faqih: Sebuah Studi Pengantar. Juga membahas secara umum wilayatul faqih yang digunakan dalam struktur pemerintahan Republik Islam Iran. ${ }^{11}$

Dari beberapa kajian di atas penelitian ini mempunyai beberapa kekhususan; Pertama, sejauh pengetahuan penulis belum ada yang secara khusus membahas mengenai budaya struktur hubungan kekuasaan eksekutif dan legislatif dalam teori politik Islam, dalam hal ini telaah terhadap wilayatul faqih dalam struktur pemerintahan Republik Islam Iran. Kedua, penelitian ini akan mengkaji bagaimana membudayakan mekanisme interaksi kekuasaan antara lembaga-lembaga tersebut terutama dalam studi politik dan pemerintahan dalam Islam, karena selama ini kajian hubungan kekuasaan eksekutif, legislatif dan yudikatif yang ada merupakan kajian-kajian dari studi politik dan pemerintahan yang umum atau konvensional. Ketiga bagaimana pengaruh yang kemudian tumbuh dan berkembang 30 tahun konsep wilayatul faqih di dunia internasional

\footnotetext{
${ }^{11}$ Milani, "The Transformation of The Velayat-i-Faqih Institusion: From Khomeini to Khemenei,, dalam jurnal (The Muslim Word, Vol.LXXXII, July-October 1992, No. 3-4 h.175-190); Moussawi, Ahmad, "Teori Wilayat Faqih: Asal Mula dan Penampilannya dalam Literatur Hukum Syi'ah," dalam Masalah-Masalah Teori Politik Islam (ed. Mumtaz Ahmad), Bandung: Penerbit Mizan,1993.
}

khususnya Negara-negara berpenduduk mayoritas muslim.

\section{Masalah Penelitian}

Penelitian ini membatasi permasalahan pada sejarah sosial Iran yang memunculkan sistem wilayatul faqih, biografi Imam Khomeini, pengertian wilayatul faqih, Budaya sistem wilayatul faqih dalam struktur pemerintahan Republik Islam Iran, dan prospek sistem ini tata pemerintahan Islam di masa yang akan datang.

\section{Tujuan Penelitian}

1. Mendeskripsikan dan memberikan penjelasan mengenai sebab munculnya dan definisi gagasan Imam Khomeini yaitu wilayatul faqih.

2. Menjelaskan Budaya wilayatul faqih dalam struktur pemerintahan Republik Islam Iran .

3. Mencoba melihat prospek sistem wilayatul faqih dalam tata pemerintahan Islam di masa yang akan datang.

\section{Manfaat Penelitian}

1. Pada dataran teoritis, hasil penelitian ini diharapkan memberikan sumbangan pemahaman terhadap analisis mengenai struktur pemerintahan Republik Islam Iran dengan harapan nantinya dapat dikembangkan dan dijadikan acuan untuk penelitian lebih lanjut.

2. Dalam dataran praktis, hasil penelitian ini diharapkan memberikan sumbangan informasi dan pemahaman yang lebih mendalam terhadap sistem wilayatul faqih dan prospeknya dalam tata pemerintahan Islam di masa yang akan datang.

\section{KERANGKA TEORI}

\section{Sistem dan Struktur}

Sistem adalah sekumpulan obyek atau elemenelemen yang tergabung dalam suatu interaksi dan inter-dependensi yang teratur untuk mencapai tujuan tertentu. Di dalam sistem terdapat suatu jaringan kerja dari prosedur-prosedur yang saling berhubungan, bersama-sama melakukan suatu kegiatan atau untuk menyelesaikan suatu sasaran yang tertentu. ${ }^{12}$

\footnotetext{
${ }^{12}$ http://one.indoskripsi.com/judul-skripsimakalah-tentang/sistem
} 
Suatu sistem pasti mempunyai tujuan atau sasaran. Kalau suatu sistem tidak mempnyai sasaran, maka operasi sistem tidak akan ada gunanya. Sasaran dari sistem sangat menentukan sekali masukan yang dibutuhkan sistem dan keluaran yang akan dihasilkan sistem. Suatu sistem dikatakan berhasil bila mengenai sasaran atau tujuannya. Perbedaan suatu sasaran (objectives) dan suatu tujuan (goal) adalah, goal biasanya dihubungkan dengan ruang lingkup yang lebih luas dan sasaran dalam ruang lingkup yang lebih sempit.

Setiap sistem harus punya input (masukan), output (keluaran), dan proses. Jika keluaran yang dihasilkan tidak sesuai, lihat umpan balik (feedback) dan bila perlu adakan percepatan (fast forward). Sistem terbuka adalah sistem yang berhubungan dan terpengaruh dengan lingkungan luarnya. Sistem ini menerima masukan dan menghasilkan keluaran untuk lingkungan luar atau subsistem yang lainnya.

Struktur adalah bagaimana bagian-bagian dari sesuatu berhubungan satu dengan lain atau bagaimana sesuatu tersebut disatukan. Struktur adalah sifat fundamental bagi setiap sistem. Identifikasi suatu struktur adalah suatu tugas subjektif, karena tergantung pada asumsi kriteria bagi pengenalan bagian-bagiannya dan hubungan mereka. Karenanya, identifikasi kognitif suatu struktur berorientasi tujuan dan tergantung pada pengetahuan yang ada.

Struktur adalah bangunan (teoritis) yang terdiri atas unsur-unsur yang berhubungan satu sama lain dalam satu kesatuan. Struktur ada struktur atas, struktur bawah. Struktur mempunyai sifat : Totalitas Transformatif Otoregulatif.

\section{Islam dan Demokrasi}

Pemikiran politik Islam kontemporer telah banyak dipengaruhi oleh upaya-upaya rekonsiliasi antara Islam dan demokrasi. Para pemikir Islam yang terlibat dalam perdebatan politik tidak dapat mengabaikan signifikansi dari struktur demokrasi, yang merupakan tema yang masih terus diperbincangkan dalam struktur politik Barat modern. ${ }^{13}$ Dalam hal ini penting bagi setiap struktur politik alternatif, baik yang religius maupun sekuler, untuk mengeksplorasi posisinya dalam kaitannya dengan pemerintahan demokrasi. Lalu, bagaimana persinggungan Islam dengan demokrasi?.

\footnotetext{
${ }^{13}$ Vaezi, Agama, hlm. 189.
}

Persinggungan yang terjadi antara Islam dan demokrasi sebenarnya merupakan bagian atau konsekuensi logis dari pertemuan antara wacana politik Islam dan wacana politik Barat. ${ }^{14}$ Persinggungan ini berakar dari pertemuanpertemuan sejarah yang terjadi selama bertahuntahun, hingga akhirnya menimbulkan sintesissintesis politik yang dalam banyak hal justru saling memperkaya. Apresiasi kalangan Islam terhadap struktur demokrasi, sesungguhnya merupakan fenomena yang tidak berdiri sendiri dan terus berproses. ${ }^{15}$

Demokrasi merupakan sebuah sistem yang didambakan oleh hampir setiap insan politik. Hampir tidak ada satu rezim pun di dunia ini baik di negara-negara kapitalis maupun komunis, maju maupun berkembang yang enggan mencantumkan baik secara eksplisit maupun implisit, kata "demokrasi" pada sistem politik yang dianut negaranya. Kendati dengan berbagai macam tambahan di belakangnya, "demokrasi" dianut oleh sebagian besar Negara di dunia ini. ${ }^{16}$

Menurut Robert A. Dahl, dewasa ini para diktator sekalipun percaya bahwa komponen yang harus bagi keabsahan mereka adalah terdapatnya satu dua kata tentang demokrasi. Inti demokrasi yang stabil akan terus mempunyai pengaruh yang besar di dunia; di kebanyakan negara, para pemimpinnya akan terus menyebut "pemerintahan oleh rakyat" sebagai suatu sendi bagi keabsahan mereka; ironisnya dari mereka tidak menggunakan konsep demokrasi secara utuh dalam praktek pemerintahannya. ${ }^{17}$

Istilah "demokrasi" berasal dari bahasa Yunani, yaitu demos yang berarti "rakyat", dan Kratia yang berarti "pemerintahan". Yang menjadi permasalahan adalah apakah demos di sini memiliki makna rakyat seperti yang kita pahami selama ini? Tampaknya tidak. Apa yang sesungguhnya dianggap sebagai "rakyat" di Yunani kuno (Athena), menurut Dahl, berbeda sekali dengan apa yang mungkin kita pahami apabila menyebut kata "rakyat". Menurut definisi

\footnotetext{
${ }^{14}$ Mortimer, dalam bukunya Islam dan Kekuasaan (Bandung : Mizan, 1984), hlm. 70.

15 Urbaningrum, Islamo Demokrasi: Pemikiran Nurcholis Madjid (Jakarta: Republika, 2004), hlm. 79.

${ }^{16}$ Sihbudi. Menyandera Timur Tengah. (Jakarta: Mizan, 2007), hal. 2.

${ }^{17}$ Dahl. Demokrasi dan Para Pengkritiknya. (Jakarta: YAyasan Obor Indonesia. 1992) hal 20.
} 
Yunani kuno, "rakyat" tidak lebih dari sekumpulan manusia dari sebuah polis atau kota kecil.

Semua syarat itu jelas tidak bias dipenuhi oleh demokrasi "modern". Dari segi perspektif demokrasi kontemporer, batas yang penting sekali dari demokrasi Yunani tersebut, dalam teori maupun praktik, adalah bahwa kewarganegaraan amat eksklusif dan bukan inklusif seperti yang terdapat dalam demokrasi modern. Demokrasi model Yunani mendapat kritik tajam dari tokohtokoh seperti Aristoteles. Memang "demokrasi" dewasa ini seperti yang dikatakan Dahl, "tidak lagi istilah yang mempunyai pengertian terbatas dan khas. Lebih banyak merupakan penerimaan yang kabur dari sebuah gagasan yang populer. ${ }^{18}$

Kaum republiken yang aristokratis memandang, fungsi rakyat yang sesungguhnya bukanlah memerintah, seperti di Athena, tetapi memilih pemimpin yang memenuhi syarat untuk melaksanakan tugas cukup berat yaitu memerintah seluruh negara. Pada tahapan ini pengertian demokrasi sudah mulai bergeser. dari demokrasi di mana rakyat secara langsung melakukan legislasi menjadi demokrasi yang bersifat partisipatif. Agar suatu negara dapat diperintah secara demokratis diperlukan dua syarat utama yaitu: pertama, militer dan polisi harus berada di bawah pengawasan sipil; kedua, sipil yang mengendalikan militer dan polisi tersebut harus tunduk pada proses demokrasi. Di samping itu, diperlukan suatu tatanan yang disebut dengan poliarki, yaitu suatu tatanan politik yang pada tingkatnya yang paling umum dibedakan oleh dua ciri: kewarganegaraan diperluas sampai mencakup bagian yang relatif tinggi dari orang dewasa, dan hak-hak kewaganegaraan mencakup kesempatan untuk menentang dan memberhentikan para pejabat tinggi dalam pemerintahan dengan melalui pemberian suara.

Menurut David E. Apter, orang tidak akan bisa berbicara tentang kebebasan tanpa adanya oposisi yang teratur dan sah, satu parlemen atau yang semacamnya, sistem multipartai dan sebagainya. Suatu masyarakat yang demokratis membutuhkan adanya kebebasan, pemilu, lembaga-lembaga perwakilan dan segala yang berhubungan dengan itu. ${ }^{19}$ Dalam pandangan Dahl, negara demokrasi yang maju adalah suatu negara suatu yang

\footnotetext{
${ }^{18}$ Sihbudi. Menyandera Timur Tengah.(Jakarta: Mizan. 2007). Hal. 4.

${ }^{19}$ Apter. Politik Modernisasi. (Jakarta: Gramedia. 1987) hal. 469 dikutip dari Riza Sihbudi.Menyandera TimurTengah. (Jakarta: Gramedia. 2007) hal 5.
}

dinamakan MDP (modern, dynamic, plurakist). Namun menurutnya, demokrasi itu pada hakekatnya bukan tujuan pada dirinya, melainkan melainkan suatu saran untuk mencapai tujuan yang lebih mulia, yaitu kebebasan, perkembangan manusia dan nilai manusia. Nilai-nilai tersebut tidak terpecah-pecah namun terpadu: kebahagiaan bersatu dengan kebajikan, kebajikan bersatu dengan keadilan dan keadilan bersatu dengan kebahagiaan. Keadilan di samping kebebasan memang menjadi salah satu kunci dalam demokrasi.

Pandangan Dahl tersebut tampaknya disepakati oleh Apter yang mengatakan bahwa yang merupakan persyaratan umum agar suatu masyarakat bisa tumbuh adalah, masalah-masalah kekuasaan harus diubah menjadi masalah keadilan. Keadilan adalah sebagai landasan solidaritas berarti rasa keadilan yang nyata dipunyai oleh masyarakat umum, dan prosedur-prosedur politik yang teratur secara terus-menerus meninjau kembali definisi keadilan. ${ }^{20}$

Gagasan demokrasi juga menganggap ada tiga jenis persamaan: pertama, persamaan moral intrinsik dari semua orang; kedua, persamaan yang dinyatakan dalam anggapan bahwa orang dewasa berhak memiliki otonomi pribadi dalam menentukan apa yang terbaik bagi diri mereka; dan, ketiga, persamaan politik di kalangan warga Negara. Namun, Dahl mengakui demokrasi bukanlah sebuah sistem yang terbebas dari kritik. Para pengkritik demokrasi justru datang dari para pendukung demokrasi itu sendiri. Bahkan, menurut Dahl, "kehancuran demokrasi lebih banyak disebabkan oleh pendukungnya yang utopis daripada musuhnya". Dahl membagi para pengkritik demokrasi menjadi tiga golongan. Pertama. Mereka yang seperti Plato, percaya bahwa meskipun demokrasi itu mungkin diciptakan, tetapi tidak diinginkan; kedua, mereka yang seperti Robert Michels,, percaya bahwa meskipun demokrasi itu disenangi bila diciptakan, namun pada dasarnya tidak bisa diciptakan. Dan, ketiga, mereka yang bersimpati pada demokrasi dan ingin mempertahankannya, namun mengkritiknya dipandang dari beberapa segi penting.

Tentang "kelemahan" demokrasi, Apter pernah mengatakan, ${ }^{21}$ apakah warga Negara, sebagai suatu

\footnotetext{
${ }^{20}$ Ibid

${ }^{21}$ Apter. Pengantar Analisa Politik. (Jakarta: LP3ES: 1985) hal. 216.
} 
massa atau agregat, mampu membuat keputusankeputusan rasional dan efektif? Atau, atas nama demokrasi dan rasionalitas yang menjadi cita-cita pencerahan: apakah warga Negara menjadi korban politisi? Dan, jika demikian apakah demokrasi merupakan sebuah doktrin yang cacat, bagaimanapun baiknya cita-cita, kalau suatu pendapat umum yang cerdas tidaklah mungkin? Terlepas dari kelebihan dan kekurangan sistem demokrasi tersebut, John L. Esposito dan John O. Voll berpendapat bahwa model demokrasilah yang diakui secara resmi dan berbagai konsep demokrasi di dunia barat juga berpengaruh terhadap proses demokratisasi di dunia Islam, khususnya di negaranegara kawasan Timur-Tengah. Dan, dengan sendirinya perdebatan antara "model resmi" sistem demokrasi barat dan kritik-kritiknya yang terjadi belakangan ini juga mempengaruhi respon kaum muslim terhadap kebijakan barat dan perubahan di tingkat lokal. ${ }^{22}$

Pertama, bagi kelompok yang menolak demokrasi beranggapan bahwa adalah impossible jika Islam memiliki kesamaan dengan demokrasi. Mereka berpendapat bahwa dalam Islam tidak ada tempat yang layak bagi demokrasi, yang karenanya Islam dan demokrasi tidak dapat dipadukan. Beberapa ulama yang berpandangan demikian antara lain adalah, Syaikh Fadillah Nuri, Thabathabai, dan Sayyid Qutb. Bagi Syaikh Fadillah Nuri, salah seorang ulama Iran, satu kunci gagasan demokrasi yaitu persamaan semua warga negara adalah impossible dalam Islam. Perbedaan luar biasa yang tidak mungkin dihindari pasti terjadi, misalnya, antara yang beriman dan yang tidak beriman, antara kaya dan miskin, dan antara faqih (ahli hukum Islam) dan pengikutnya. ${ }^{23}$ Selain itu, ia juga menolak legitimasi oleh manusia karena Islam menurutnya, tidak memiliki kekurangan yang memerlukan penyempunaan. Dalam Islam tidak ada seorangpun yang diizinkan mengatur hukum. Paham konstitusional sebagai bagian dari demokrasi, karenanya bertentangan dengan Islam. dalam keyakinan Syaikh Fadillah Nuri, tampaknya manusia hanya bertugas melaksanakan hukumhukum Tuhan. ${ }^{24}$

\footnotetext{
${ }^{22}$ Dalam buku mereka, Demokrasi di Negara-negara muslim: problem dan prospek.(Jakarta: Mizan. 1999) hal. 24

${ }^{23}$ Kamil, Islam dan Demokrasi: Telaah Strukturtual dan Historis (Jakarta: Gaya Media Pratama, 2002), hlm 47-48 ; Ira M. Lapidus, Sejarah Sosial Umat Islam, Bagian 3, terj. Ghufron A. Mas'adi (Jakarta: Raja Grafindo Persada, 1999), hlm. 38-39.

${ }^{24}$ Kamil, Islam, hlm. 48.
}

Sayyid Qutb, Pemikir Ikhwanul Muslimin, sangat menentang gagasan kedaulatan rakyat. Baginya, hal itu adalah pelanggaran terhadap kekuasaan Tuhan dan merupakan suatu bentuk tirani sebagian orang terhadap yang lainnya. Mengakui kekuasaan Tuhan berarti melakukan pertentangan secara menyeluruh terhadap seluruh kekuasaan manusia dalam seluruh pengertian, bentuk, struktur, dan kondisi. Agresi menentang kekuasaan Tuhan di atas bumi merupakan suatu bentuk jahiliyah (kebodohan pra Islam), sambil menekankan bahwa sebuah negara Islam harus berlandaskan pada prinsip musyawarah, ia percaya bahwa syari'ah sebagai sebuah struktur hukum dan struktur moral sudah sangat lengkap, sehingga tidak ada legitimasi lain yang mengatasinya. ${ }^{25}$

Kendati berbeda akar keberatannya, Thabathabai, seorang mufassir dan filosuf terkenal Iran, berpendapat bahwa Islam dan demokrasi menurutnya tidak bisa dirujukan karena prinsip mayoritasnya. Setiap agama besar, dalam kelahirannya selalu bertentangan dengan kehendak mayoritas. Makhluk manusia sering tidak menyukai yang adil dan benar. Ia mengutip ayat: "Seandainya kebenaran itu mengikuti kehendak mereka sendiri pasti akan binasalah langit dan bumi beserta isinya". ${ }^{26}$ Karena itu, menurutnya salah jika menganggap tuntunan mayoritas selalu adil dan mengikat ${ }^{27}$ seperti yang dikehendaki oleh demokrasi barat.

Kedua, Kelompok yang menyetujui adanya prinsip-prinsip demokrasi dalam Islam tetapi mengakui adanya perbedaan. Kelompok ini diwakili oleh Maududi di Pakistan dan Imam Khomeini dari Iran, serta beberapa pemikir Islam lainnya.

Menurut Maududi suatu negara yang telah didirikan dengan dasar kedaulatan de jure Tuhan tidak dapat melakukan legitimasi bertolakbelakang dengan ketentuan-Nya (al-Qur'an dan Hadits), sekalipun konsensus menuntutnya. Tetapi menurutnya bukan tidak ada peluang bagi manusia untuk membuat legitimasi sendiri, semua urusan administrasi dan masalah yang tidak ditemui penjelasannya secara gamblang dalam syariah ditetapkan berdasarkan konsensus di antara sesama

\footnotetext{
${ }^{25}$ Ibid., hlm 48.

${ }^{26}$ Q.S. al-Mu'minuun: 70-71.

${ }^{27}$ Kamil, Islam, hlm. 48 ; Hamid Enayat, Reaksi Politik Sunni dan Syi'ah, Pemikiran Islam Modern Menghadapi Abad 20, (Bandung: Pustaka, 1988), hlm. 21.
} 
kaum Muslim yang memiliki kualifikasi. Dalam hal struktur tersebut mengambil jalan tengah (moderat) dan Maududi menyebutnya struktur pemerintahan "Teo-Demokrasi". Yaitu suatu struktur pemerintahan demokrasi Ilahi, suatu struktur kedaulatan rakyat yang dibatasi kedaulatan Tuhan lewat hukum-hukumnya. ${ }^{28}$

Khomeini mempunyai pandangan lain terhadap demokrasi, menurutnya demokrasi Islam berbeda dengan demokrasi liberal, Ia meyakini bahwa kebebasan mesti dibatasi dengan hukum, dan kebebasan yang diberikan itu harus dilaksanakan di dalam batas-batas hukum Islam dan konstitusi, dengan sebaik-baiknya. ${ }^{29}$ Konstitusi Republik Islam Iran yang didasarkan pada wilayatul faqih mencerminkan bahwa di satu sisi Iran merupakan negara Islam yang bersumber pada hukum agama, namun di sisi lain Iran merupakan sebuah negara yang secara prinsipil menganut struktur demokrasi.

Ketiga, kelompok yang menerima sepenuhnya struktur demokrasi memandang bahwa sejatinya di dalam diri Islam sangat demokratis karenanya menurut mereka Islam menerima sepenuhnya demokrasi sebagai sesuatu yang universal. Pemikir yang masuk dalam kategori kelompok ketiga ini antara lain, Muhammad Husain Haikal dari Mesir, Rashid al-Ghannouchi, pemikir politik asal Tunisia, serta Bani Sadr dan Mehdi Bazargan dari Iran.

Muhammad Husein Haikal, salah seorang pemikir muslim dari Mesir, berpendapat bahwa dalam dunia pemikiran, demokrasi pertama kali dicanangkan oleh Islam, menurutnya, semua struktur yang tidak berdiri di atas prinsip-prinsip demokrasi adalah tidak sesuai dengan kaidahkaidah utama yang ditetapkan dan diserukan Islam. Karena, kaidah-kaidah yang ditetapkan demokrasi merupakan kaidah Islam dan begitu pula dengan prinsip-prinsipnya. Islam dan demokrasi samasama berorientasi kepada fitrah manusia. Haikal mendasarkan pikirannya kepada prinsip musyawarah, prinsip persaudaraan Islam, prinsip persamaan, prinsip ijtihad (penalaran pribadi) atau kebebasan berpikir terutama dalam masalah yang tidak ada kaitannya dengan syariah. prinsip legitimasi yang wewenangnya hanya dimiliki oleh para hakim dan tidak dimiliki oleh khalifah atau imam, prinsip ijma' (kesepakatan para ahli), pengawasan terhadap penguasa, akuntabilitas serta

\footnotetext{
${ }^{28}$ Maududi, Hukum dan Konstitusi Struktur Politik Islam, terj. Asep Hikmat dari The Islamic Law and Government (Bandung: Mizan, 1990), hlm. 160-161

${ }^{29}$ Yamani, Filsafat, hlm. 141.
}

pengendalian nafsu bagi penguasa. Semua itu merupakan prinsip-prinsip dari struktur politik yang dipraktikkan Nabi di Madinah. ${ }^{30}$

Pendukung-pendukung demokrasi Islam biasanya merujuk pada syura (konsultasi) sebagai ajaran Islam terpenting yang mendukung dan menjustifikasi otoritas rakyat dalam suatu pemerintahan Islam. Rashid al-Ghannouchi, pemikir politik asal Tunisia menulis, bahwa pemerintahan Islam adalah pemerintahan yang antara lain mencakup; (1) Otoritas legislatif tertinggi adalah Syari'ah, yang merupakan hukumhukum Ilahiyah dari Islam yang mengatasi semua hukum-hukum. Konteks ini adalah menjadi tanggung jawab ulama untuk mendeduksikan hukum-hukum dan peraturan-peraturan yang terperinci sebagai bimbingan bagi hakim-hakim. Kepala negara dalam pemerintaan Islam adalah pemimpin dari badan eksekutif yang diserahi tanggung jawab untuk mengBudayakan hukumhukum dan peraturan-peraturan itu; (2) kekuasaan politik ada di tangan masyarakat (ummah), yang harus mengadopsi bentuk "syura" sebagai suatu struktur konsultasi mandat. ${ }^{31}$

Pemikir Islam lain seperti Sadek Sulaiman asal Oman, menegaskan bahwa syura dalam Islam termasuk unsur-unsur pokok dalam demokrasi, ia berkata:

"Sebagai sebuah struktur dan sebuah
prinsip, syura dalam Islam tidak
berbeda dengan demokrasi, baik syura
maupun demokrasi muncul dari
pertimbangan pokok bahwa diskusi
kolektif lebih cenderung membawa
suatu hasil yang adil dan sehat untuk
kepentingan sosial ketimbang
preferensi individual"32

Apa yang membuat syura sebagai satu unsur mendasar dari demokrasi dalam Islam, adalah kenyataan bahwa syura merujuk pada salah satu esensi-esensi penting dari demokrasi. Demokasi dalam sejarahnya yang panjang telah mengalami perubahan-perubahan, tetapi masalah-masalah seperti partisipasi publik, peraturan hukum dan pertanggungjawaban dari penguasa dapat dikatakan esensial bagi demokrasi. Kesimpulannya adalah asumsi bahwa struktur politik Islam demokratis, mengandung pengertian bahwa ajaran-ajaran

\footnotetext{
${ }^{30}$ Kamil, Islam, hlm. 58-59

${ }^{31}$ Vaezi, Negara, hlm. 232

${ }^{32}$ Ibid., hlm. 233.
} 
Islam mendukung dan menyetujui esensiesensi demokrasi.

Salah seorang ilmuwan politik, Samuel P. Huntington, dalam sebuah artikelnya, "Religion and the Third Wave" ${ }^{33}$ membuat ulasan panjang lebar mengenai korelasi agama-agama besar dengan proses demokratisasi di berbagai belahan dunia. Menurutnya protestan merupakan agama pertama yang mendorong terjadinya proses demokratisasi. Ia mengutip hasil penelitian Kenneth A. Bollen (1979) yang menyimpulkan bahwa di negara-negara berpenduduk mayoritas protestan, tingkat demokrasinya lebih tinggi ("the greater the proportion of the population that is protestant, the higher the level of democracy"). Sebaliknya, katolik menjadi agama "penghambat" demokratisasi. Lantas bagaimana dengan Islam? Menurutnya Islam masih menjadi penghambat demokratisasi. Ia menunjuk pada sejarah bahwa hingga menjelang akhir abad ke-20 belum ada satu pun Negara berpenduduk mayoritas muslim yang menganut sistem demokrasi secara utuh ( a fully democratic political sistem).

\section{Konsep Kepentingan Nasional}

Kepentingan nasional (national interest) adalah konsep yang digunakan dalam menganalisa hubungan internasional, baik dalam mendeskripsikan, meramalkan, maupun menganjurkan perilaku internasional. Konsep kepentingan nasional sebagai dasar menjelaskan perilaku luar negeri suatu negara.

Morgenthau menyatakan bahwa kepentingan nasional setiap negara adalah mengejar kekuasaan, yaitu apa saja yang bisa membentuk dan mempertahankan pengendalian suatu negara terhadap negara lain. ${ }^{34}$ Hubungan kekuasaan atau pengendalian ini bisa diciptakan melalui teknikteknik paksaan maupun kerjasama.

Morgenthau yang meletakkan dasar pemahaman utuh perihal karakteristik power dalam hubungan antarnegara. Secara kasatmata, power berwujud dalam bentuk paksaan (force), baik yang bersifat militeristik maupun yang non-militeristik, seperti blokade, sanksi perdagangan, sanksi militer dan sebagainya. Namun power juga dapat berbentuk hubungan psikologis melalui kemampuan

\footnotetext{
${ }^{33}$ Dalam The National Interest (Summer. 1991), hal. 2941

${ }^{34}$ Dikutip dari Mas'oed, Ilmu Hubungan Internasional: Disiplin dan Metodologi, Jakarta, LP3ES, 1990, hlm. 140.
}

mempengaruhi (influence) pihak lain untuk secara sadar bertindak sesuai dengan yang diharapkannya.

Menurut Couloumbis dan Wolfe, power sebagai paying konsep memiliki tiga unsur yaitu: ${ }^{35}$

1. Force (Kekuatan), yang didefinisikan sebagai ancaman eksplisit, atau aktor A menggunakan alat-alat paksa seperti militer, ekonomi dan lain sebagainya kepada aktor B untuk mencapai tujuan-tujuan politik.

2. Influence (Pengaruh), yang didefinisikan sebagai penggunaan alat-alat persuasi oleh aktor A untuk menjaga dan merubah perilaku aktor $\mathrm{B}$ dengan cara-cara yang sesuai dengan preferensi atau keinginan aktor A.

3. Otoritas, yang didefinisikan sebagai kerelaan aktor B untuk memenuhi intruksi-intruksi yang dikeluarkan oleh aktor A yang dipelihara dalam persepsi aktor B mengenai aktor A, seperti sikap hormat, solidaritas dan kepemimpinan.

\section{HASIL DAN PEMBAHASAN}

\section{Analisis Budaya Sistem Wilayatul Faqih dalam Struktur Pemerintahan Republik Islam Iran}

\section{Revolusi Islam Iran}

Pada akhir dekade 70-an, Dunia dikejutkan dengan peristiwa revolusi Islam yang terjadi di Iran. Revolusi yang oleh beberapa pengamat Barat seperti Jhon L Esposito disebut sebagai "salah satu pemberontakan rakyat terbesar dalam sejarah umat manusia" tersebut berhasil menggulingkan rezim otoriter pimpinan Reza Syah Pahlevi. ${ }^{36}$ Revolusi ini merupakan hasil suatu protes akumulasi ketidakpuasan rakyat Iran terhadap kebijaksanaan Syah, baik di bidang ekonomi, politik, agama, maupun sosial budaya. Keberhasilan revolusi itu banyak ditentukan oleh dua faktor yang saling berkaitan satu sama lain. Di satu pihak terciptanya persatuan di antara kelompok-kelompok penentang Syah, baik yang berfaham nasionalisme (Front Nasional), Islamisme (organisasi- organisasi yang dibentuk kaum mullah maupun yang berfaham marxisme (Mujahiddin dan Fayden Khalq). Di pihak lain muncul kelompok Ulama seperti Ayatullah Murthadha Munthahari, Ayatullah Khomeini sebagai lambang "pemersatu", serta

\footnotetext{
${ }^{35}$ Couloumbis dan James H. Wolfe alih bahasa

Marcedes Marbun, Pengantar Hubungan

Internasional Keadilan dan Power, 1990. Hlm. 87.

${ }^{36}$ Esposito, Demokrasi, hlm. 66,
} 
tokoh intelektual awam seperti Ali Syari'ati sebagai strukturator akar Ideologi revolusi, Mehdi Bargazan, Bani Sadr, dan tokoh-tokoh lainnya. Hal ini dimungkinkan oleh tradisi dan ideologi Syi'ah yang sangat berakar kuat di kalangan rakyat Iran. ${ }^{37}$ Ideologi Syi'ah tersebut yang kemudian menjadi salah satu pemantik terjadinya revolusi Iran.

Revolusi Islam Iran ini melahirkan konfigurasi yang khas antara negara Iran dan Institusi Islam, bahkan revolusi ini merupakan sebuah peristiwa terbesar dalam sejarah masyarakat Iran. Revolusi tersebut menandai puncak pergolakan politik antara penguasa Iran dan kelompok ulama yang telah berlangsung lama, akibatnya terjadi perubahan yang fundamental dalam sistem ketatanegaraan Iran yang berpengaruh terhadap sistem pemerintahan Iran sekarang.

Struktur politik Iran mengalami perubahan secara besar-besaran sejak berakhirnya kekuasaan Syah. Bentuk negara berubah dari monarki-absolut di mana Syah berkuasa, menjadi sebuah republik yang berdasarkan pada ajaran agama Islam mazhab Syi'ah. Perubahan konstitusional dan institusional yang secara substantif dilakukan melalui pemilihan. Bentuk Republik Islam secara resmi disetujui 98,2\% masyarakat Iran melalui referendum yang diadakan pada 1 April 1979 dan Undang-undang Dasar Republik Islam Iran secara resmi disetujui 99,5\% rakyat Iran melalui referendum yang diadakan pada 3 Desember $1979^{38}$.

Majelis Ahli yang didominasi para ulama dipilih untuk membuat rancangan konstitusi, masih menyisakan krisis identitas Iran yang tercermin dalam perdebatan konstitusional mengenai hakikat kepemimpinan negara. Perdebatan-perdebatan terjadi tidak hanya antara pihak yang lebih menginginkan pemerintahan sekuler daripada pemerintahan islami, tetapi juga di antara pihak yang menginginkan Pemerintah Islam namun menolak doktrin wilayatul faqih dari Imam

\footnotetext{
${ }^{37}$ Sihbudi, Revolusi, hlm.114. Perlu dicatat bahwa Ideologi Syi'ah yang berakar kuat dalam keyakinan masyarakat Iran sangat berpengaruh besar terhadap keberhasilan revolusi Islam Iran. Aktor Intelektual revolusi Islam Iran selain Imam Khomaeni adalah Ali Syari'ati, ia berhasil menerjemahkan secara mudah ideologi Syi'ah menjadi revolusioner dengan paradigma sosiologis Marxis.

${ }^{38}$ Sihbudi. Biografi Politik Imam Khomeini.(Jakarta:

Gramedia Pustaka Utama. 1996). Hal 80
}

Khomeini yang menjadikannya sebagai seorang marja taqlid (ahli otoritas tertinggi) ${ }^{39}$

Bagi masyarakat dunia Islam, Revolusi Islam Iran merupakan kejadian yang secara simbolis penting. Revolusi Iran memperlihatkan bahwa rezim sekuler yang dipengaruhi oleh Barat dapat ditumbangkan dengan kekuatan oposisi yang di organisasi oleh para pembaharu Islam. Karena kaum revivalis mendengungkan perubahan itu sejak akhir abad ke-19, namun dengan sukses, revolusi Islam ini mampu memberikan daya dorong baru bagi perjuangan mereka dan memicu munculnya aktivitas fundamentalis di dunia Islam lain.

Dapat dikatakan bahwa meskipun ketegangan dinamis bagi oposisi terhadap monarki telah lama ada di Iran, tidak seorangpun Muslim meramalkan dengan pasti bahwa hasil akhir revolusi berupa pemerintahan teokratis. Bagi kaum Muslim yang menginginkan pembaharuan dan ingin lepas dari dominasi Barat, revolusi Islam Iran merupakan kejadian yang sangat memberikan ilham. Bagi kaum nasionalistik sekuler dan sebagian dunia Barat, revolusi ini terus mengusik. Akan tetapi, sepanjang periode ini peran dari sosok Ayatullah Ruhullah Khomeini sangat menonjol. Tidak salah apabila Jhon L. Esposito menyebut Imam Khomeini sebagai "living symbol and architect" revolusi Iran. ${ }^{40}$ Karena peranannya dalam memimpin revolusi Iran itulah, Khomeini diangkat sebagai pemimpin Revolusi Islam, sebagaimana yang tercantum dalam konstitusi Iran yang disahkan Desember 1979. Dalam buku Islamic Revolution of Iran, Imam Khomeini dianggap sebagai "wakil" Imam Mahdi: "In conclution we once again declare our complete solidarity with people of Iran by resorting tu hunger strike and similar action and waiting for arrival of the deputy to al-'Imam Muhammad al-Mahdi (AS), Imam Khumayni". ${ }^{41}$

\section{Analisis Struktural kalimat Wilayatul faqih}

Struktur kata wilayatul faqih merupakan poros sentral dari pemikiran Syi'ah kontemporer yang mengadopsi sistem politik yang berbasiskan perwalian. Struktur ini muncul dari doktrin Imamah yang merupakan basis paham Syi'ah, berikut ini di analisis secara strukturtual mengenai pengertian dari wilayatul faqih.

\footnotetext{
${ }^{39}$ Ibid., hlm. 79-80.

${ }^{40}$ John. L. Esposito, Islam dan Politik, terj. Jusup Soe’yb (Jakarta: Bulan Bintang, 1990), hlm. 196.

${ }^{41}$ Sihbudi, Biografi, hlm. 60.
} 
Dalam bahasa Arab, kata 'wilayah' berakar dari kata wali yang menurut istilah kalangan leksikograf Arab terkemuka merupakan unit terkecil dalam bahasa yang mengandung makna tunggal; kedekatan daya tarik/ hubungan dekat/ persamaan/ pertalian. Dalam bahasa Arab terdapat tiga makna yang tercatat untuk kata 'wali': (1) teman; (2) setia/ berbakti; (3) Pendukung atau Penyokong. Di samping ketiga arti ini, dua arti lain disebutkan untuk kata 'wilayah': (1) kekuasaan (tertinggi) dan penguasaan; (2) kepemimpinan dan pemerintahan ${ }^{42}$ Dalam bahasa Persia, kata wali memiliki sederet arti, seperti teman, pendukung, pemilik, pelindung, pembantu, dan penjaga. Begitu pula kata wilayah, yang bermakna mengatur dan memerintah. Kata wilayah dalam wilayatul faqih bermakna pemerintahan dan administrasi atau pengelolaan. Sebagian kalangan meletakkan makna ini untuk mendapatkan pengertian 'pengendalian atau kontrol, penguasaan, jabatan, hakim, dan kekuasaan tertinggi yang menunjukkan otoritas wali (sang pembawa wilayah) atas mawla 'alayh (orang yang bergantung pada atau menjadi objek wilayah). ${ }^{43}$ Namun demikian, wilayah yang bermakna pengawasan dan pelaksanaan urusanurusan mawla 'alayh adalah pemberi pelayanan kepada mawla 'alayh, bukan melakukan pembebanan dan pemaksaan atasnya. ${ }^{44}$

Dalam Al Qur'an kata wilayah. disebutkan hingga 236 kali. 124 kali dalam bentuk kata benda dan 112 kali dalam bentuk kata kerja. Salah satunya adalah yang terdapat pada surat Al-Maidah ayat 55 dan 56. Pada kedua ayat ini al Qur'an menggunakan kedua bentuk kata wilayah itu.

"Sesungguhnya wali (bentuk kata benda) kalian adalah Allah, Rasul-Nya dan orang-orang mukmin yang mendirikan shalat dan mengeluarkan zakat saat mereka sedang ruku'. Maka barangsiapa yang berwilayah (kata kerja: yatawallâ) kepada Allah, Rasul-Nya dan orang-orang mukmin, sesungguhnya partai Allah adalah yang menang."

Secara bahasa, wilayah atau walayah yang berakar dari kata w-l-y pada dasarnya mengandung makna kedekatan, apakah itu kedekatan jasmaniyah atau kedekatan maknawiyah. Karena itu, ia kadang berarti berteman, menolong, mencintai, mengikuti, menteladani, memimpin atau mematuhi. Karena makna-makna tersebut pada dasarnya merujuk

\footnotetext{
${ }^{42}$ Teherani, Negara Ilahiyah: Suara Tuhan, Suara Rakyat, (Jakarta: Al-Huda, 2005), hlm. 38.

${ }^{43}$ Ibid.

${ }^{44}$ Ibid.
}

pada makna adanya kedekatan antara pelaku, subyek, dan penderita. ${ }^{45}$

Menurut Ahmad Vaezi, dalam terminologi hukum Islam (fiqih), Istilah wilayah mempunyai beberapa penggunaan, di antaranya sebagai berikut; Pertama, wilayat al-qaraba, tipe otoritas wilayah ini diberikan pada seorang ayah atau kakek dari garis ayah untuk anak-anak atau mereka yang terganggu mentalnya (meskipun sampai usianya dewasa). Otoritas untuk bertindak sebagai wali didasarkan pada hubungan kekerabatan; kedua, wilayat alqada' menurut ahli fiqih Imamiyah, Imam maksum pada awalnya mempunyai otoritas tunggal untuk mengadili rakyat berdasarkan hukum dan wahyu Ilahiyah. Akan tetapi pada saat sekarang, seorang faqih yang mampu dapat mengambil tanggung jawab ini dengan Izin Imam; ketiga, wilayat alhakim, dalam hal ini, otoritas diberikan pada administrator dari hakim biasa, untuk mengawasi kepentingan-kepentingan seseorang yang tidak mampu menjalankan urusan-urusannya sendiri, seperti seseorang yang lemah pikirannya atau orang yang sakit jiwa. Bagi siapapun yang tidak mempunyai wali, ahli fiqih berkata: Hakimlah yang akan menjadi wali mereka yang tidak mempunyai wali. ${ }^{46}$ Keempat, wilayat al-mutlaqa, menurut bukti-bukti tekstual seperti pada al-Qur'an surat al-Ahzab ayat 6 , ahli fiqih Imamiah percaya bahwa Nabi dan para Imam-Imam mempunyai otoritas Ilahi atas rakyat. ${ }^{47}$ Menurut ayat tersebut, Nabi mempunyai lebih banyak hak atas para penganutnya dari hak mereka sendiri. Dengan demikian, otoritasnya yang penuh kebijaksanaan berlaku sangat efektif terhadap rakyat. Otoritas yang sama, menurut kepercayaan Syi'ah, juga diberikan kepada para Imam; dan kelima, wilayat al-ustba, menurut para ahli fiqih Sunni otoritas ini dihubungkan dengan hak waris, yang menetapkan

\footnotetext{
${ }^{45}$ Munthahari, "Wilayah: Struktur kepemimpinan dalam Islam"dari www.Google.com diunduh pada 5 januari 2009

${ }^{46}$ Lihat Vaezi, Agama, hlm. 85-86.

${ }^{47}$ Artinya “ Nabi itu (hendaknya) lebih utama bagi orang-orang mukmin dari diri mereka sendiri dan isteri-isterinya adalah ibu-ibu mereka. Orang-orang yang mempunyai hubungan darah satu sama lain lebih berhak (waris-mewarisi) di dalam Kitab Allah daripada orang-orang mukmin dan orang-orang Muhajirin, kecuali kalau kamu mau berbuat baik. Adalah yang demikian itu telah tertulis dalam Kitab (Allah) “(Q.S. Al-Ahzab, 33 : 37), al Qur'an alKariim dan Terjemahannya, (Semarang : Penerbit C.V. Toha Putra, 1989).
} 
ahli waris. Kategori wilayah yang demikian tidak dapat diterima oleh para ahli fiqih Imamiyah. ${ }^{48}$

Kata faqih, menurut Jalaludin Rahmat adalah muslim yang sudah mencapai tingkat tertentu dalam ilmu kesalehan. Seorang faqih diisyaratkan harus mengetahui semua peraturan Allah, mampu membedakan sunnah yang sahih dan yang palsu, yang mutlak dan yang terbatas, yang umum dan yang khusus. Ia juga harus mampu menggunakan akalnya untuk membedakan hadis dari situasi lain, situasi taqiyyah dan situasi lain, serta memahami kriteria yang telah ditetapkan. ${ }^{49}$ Menurut doktrin wilayatul faqih, seorang faqih mempunyai wilayah, perwalian atau pemerintahan atas masyarakat sebagai seorang pengurus atau pengelola yang mendorong masyarakat tersebut meraih apa yang diidamkan Islam.

Dari analisis struktural di atas dapat kita simpulkan bahwa wilayatul faqih dapat didefinisikan sebagai sebuah otoritas yang diserahkan kepada para fuqaha (para faqih) yang berilmu tinggi sehingga mereka dapat mengarahkan dan memberi nasihat pada umat muslim selama tidak hadirnya imam maksum. Adapun otoritas ini didapat dari Imam yang merupakan al-Hujjah (dari Allah), oleh karenanya adalah wajib untuk mentaati perintahperintahnya sebagai otoritas tunggal yang sah.

\section{Kebutuhan Akan Pemerintahan Islam}

Menurut Imam Khomeini, Islam merupakan agama yang memiliki seperangkat hukum berkenaan dengan masalah-masalah sosial yang harus dilaksanakan oleh kaum Muslim sebagai suatu kesatuan sosial, oleh karena itu menurutnya, kaum Muslim diwajibkan untuk mentaati aturan-aturan tersebut. keberadaan hukum-hukum yang telah tersusun tersebut tidaklah cukup untuk mereformasi masyarakat.

Selanjutnya menurut Imam, untuk menjadikan pelaksanaan hukum-hukum itu efektif, dan memastikan bahwa hukum-hukum tersebut dapat mendukung reformasi, maka diperlukan kekuasaan eksekutif (al-sulthah al-tanfidziyah) yang bertugas sebagai pengambil keputusan atas suatu masalah. Karenanya Allah Yang Maha Kuasa, dalam kaitannya dengan penerapan hukum-hukum tertulis (syariat), telah meletakkan bentuk pemerintahan yang dilengkapi oleh institusi eksekutif dan administratif. Imam Khomeini mengatakan:

\footnotetext{
${ }^{48}$ Vaezi, Agama, hlm. 86.

${ }^{49}$ Yamani, Filsafat, hlm. 16.
}

"A collection of laws is not enough to reform society. For a law to be an element for reforming and making people happy, it requires an executive authority. This is why God, may be praised, created on earth, in addition to the laws, a government and an executive and administrative agency". ${ }^{50}$

Untuk mewujudkan hal tersebut menurut Khomeini, Islam memerlukan kekuasaan negara dan pemerintahan, ia berargumen bahwa asSunnah dan thariqah (jalan hidup) Nabi Muhammad SAW, menyajikan bukti atas kebutuhan akan tegaknya pemerintahan. Pertama, Nabi Muhammad sendiri menegakkan sebuah pemerintahan, sebagaimana telah dibuktikan dalam sejarah, ia melaksanakan hukum-hukum Islam, menegakkan aturan-aturannya dan fungsi administrasinya dalam masyarakat. Menurut Khomeini, Nabi Muhammad SAW telah menjalankan seluruh fungsi pemerintahan seperti, mengutus orang-orang terpilihnya untuk menjadi Gubernur di daerah-daerah yang berbeda, membentuk badan kehakiman dan menunjuk seorang hakim, mengirim duta (utusan) ke berbagai negara asing, kepala suku dan para Raja, ia juga mengesyahkan berbagai perjanjian dan pakta, serta memimpin sendiri pasukan Islam di berbagai pertempuran. ${ }^{51}$

Kedua, Nabi Muhammad SAW menunjuk seorang pelaksana aturan-aturan untuk meneruskan kepemimpinan beliau yang didasari atas perintah Allah SWT. Khomeini berargumen jika Allah Yang Maha Kuasa -melalui Nabi Muhammad SAW- menunjuk seseorang yang akan menjalankan aturan sebagai masyarakat muslim sepeninggalnya, maka ini merupakan indikasi bahwa pemerintahan tetap menjadi kebutuhan setelah wafatnya Nabi. Dengan menjalankan perintah Allah melalui penunjukan seorang penerus kepemimpinan, Rasulullah SAW secara implisit menegaskan perlunya untuk menegakkan pemerintahan. ${ }^{52}$ Dengan demikian jelaslah bahwa kebutuhan akan perundang-undangan dan terbentuknya pemerintahan oleh Nabi SAW tidak terbatas pada masanya, melainkan terus berlanjut setelah Nabi wafat.

Selanjutnya Imam Khomeini mengatakan sepeninggal Nabi, kaum muslimin tetap memerlukan seseorang yang dapat mengeksekusi

\footnotetext{
${ }^{50}$ Khomeini, Islamic, hlm. 17.

${ }^{51}$ Ibid., hlm. 18.

${ }^{52}$ Ibid.
} 
(menerapkan) hukum dan menegakkan institusi Islam dalam masyarakat:

Pada asasnya, hukum dan institusi kemasyarakatan memerlukan keberadaan eksekutor. Dalam beberapa kasus, di mana saja kekuasaan legislatif yang berdiri sendiri, tidak cukup memberikan manfaat. Kekuasaan legislatif tidak dapat menjamin terwujudnya kebaikan untuk manusia. Setelah penegakan legislatif, kekuasaan eksekutif harus terbentuk. Kekuasaan inilah yang akan melaksanakan hukum dan keputusan yang telah ditetapkan oleh pengadilan. Hal ini akan menjadikan hukum-hukum lebih bermanfaat bagi manusia dan masyarakat juga akan mendapatkan keputusan adil. Kebutuhan akan berjalannya hukum Ilahi, kebutuhan akan kekuasaan eksekutif dan pentingnya kekuasaan itu dalam memenuhi tujuan-tujuan dari misi kenabian serta tegaknya aturan yang adil yang akan memberikan kebahagiaan bagi umat manusia, menurut Khomeini dapat dilakukan semuanya dengan penunjukan atas seseorang untuk menjadi penerus kepemimpinan yang merupakan pelengkap dari misi kenabian.

Dalam Hukumat-e Islami, Imam Khomeini juga sudah lebih mengelaborasi tentang apa dan bagaimana seharusnya sebuah pemerintahan Islam. Imam Khomeini menganggap pemerintahan para penguasa Dinasti Ummayah (661-750) dan Dinasti Abbasiyyah (750-1258). sebagai pemerintahan yang "anti-Islam". Karena "mereka telah mengubah sistem pemerintahan Islam sebelumnya dan mengadopsi sistem pemerintahan monarki seperti halnya kerajaan-kerajaan Romawi, Persia, dan Fir'aun di Mesir". Menurutnya seperti yang dikutip Sihbudi, bentuk pemerintahan anti-Islam seperti itu masih ada hingga saat ini. Islam, katanya tidak mengakui institusi monarki dan sejenisnya. ${ }^{53}$

Menurut Khomeini, pemerintahan Islam tidak sama dengan pemerintahan yang ada sekarang ini. Ia mencontohkan pemerintahan Islam bukan merupakan pemerintahan yang bersifat tirani, di mana para pemimpin negara dengan pemerintahan semacam ini dapat bertindak sewenang-wenang atas harta dan kehidupan rakyat mereka, memperlakukan orang sekehendak mereka dan membunuh orang yang mereka inginkan serta memperkaya seseorang yang mereka kehendaki dengan memberikan tanah dan harta milik orang lain.

\footnotetext{
${ }^{53}$ Sihbudi, Biografi, hlm. 114-115.
}

Khomeini menjelaskan bahwa Nabi Muhammad SAW, Amirul muknimin, dan para Khalifah tidak diizinkan untuk menjalankan kekuasaan seperti yang telah disebutkan di atas (kekuasaan tiran). Pemerintahan Islam tidak bersifat tirani dan tidak bersifat absolut kekuasaannya, melainkan bersifat konstitusional sebagaimana pengertian saat ini yaitu berdasarkan suara mayoritas. Pengertian konstitusional yang sesungguhnya adalah bahwa pemimpin adalah suatu subjek dari kondisi-kondisi tertentu yang telah dinyatakan dalam al-Qur'an dan Sunnah Nabi. Kondisi-kondisi tersebut merupakan hukum-hukum dan aturan-aturan Islam yang terdiri dari kondisi-kondisi yang harus diperhatikan dan dipraktikkan. Pemerintahan Islam karenanya didefinisikan sebagai pemerintahan yang berdasarkan hukum-hukum Ilahi (Tuhan) atas manusia (makhluk).

Terdapat perbedaan yang mendasar antara pemerintahan Islam dengan pemerintahan monarki atau republik. Karakteristik pemerintahan monarki adalah pemerintahan yang dipimpin oleh seorang raja (sebagai perwalian atas rakyat) dengan berdasarkan undang-undang (legitimasi), sedangkan karakteristik pemerintahan Islam, kekuasaan legislatif dan wewenang untuk menegakkan hukum secara eksklusif adalah milik Allah SWT. Pembuat undang-undang suci ini adalah satu-satunya kekuasaan legislatif. Tidak ada seorangpun yang berhak membuat undang-undang lain dan tidak ada hukum yang harus dilaksanakan kecuali hukum dari pembuat undang-undang yaitu hukum Allah SWT.

Atas dasar itulah dalam sebuah pemerintahan Islam, badan atau majelis perencanaan mengambil peran sebagai Majelis legislatif, yang merupakan salah satu dari tiga cabang kekuasaan dalam pemerintahan yang ada saat ini yaitu, kekuasaan eksekutif, kekuasaan legislatif, dan kekuasaan yudikatif. Majelis ini menyusun program-program bagi departemen-departemen kementrian di dalam rangka aturan-aturan Islam dan dengan cara demikian majelis ini akan menentukan bagaimana kuantitas dan kualitas pelayanan publik yang diberikan negara kepada masyarakatnya. Hukumhukum Islam yang ada dalam al-Qur'an dan Sunnah Nabi telah diterima kaum muslim dan ditaati. Penerimaan mereka ini memudahkan tugas pemerintah dan menerapkan hukum-hukum tersebut dan membuatnya agar tetap menjadi milik rakyat dengan mensosialisasikannya. ${ }^{54}$

\footnotetext{
${ }^{54}$ Khomeini, Sistem, hlm. 58.
} 
Sebaliknya, pada penerimaan republik atau monarki konstitusional, sebagian besar para pemimpinnya mengklaim bahwa mereka mewakili suara mayoritas rakyat, yang mana dengan suara mayoritas tersebut rakyat pasti akan mengabulkan apapun yang mereka kehendaki, kemudian memaksakan hal-hal yang menjadi kehendak mereka tersebut kepada seluruh penduduk yang dikuasainya. Pemerintahan Islam adalah pemerintahan yang berbasis hukum. Dalam pemerintahan ini, kedaulatan hanyalah milik Allah serta hukum adalah berupa keputusan dan perintahNya. Hukum-hukum ini mempunyai kewenangan mutlak atas semua individu dalam sebuah pemerintahan Islam. ${ }^{55}$

Imam Khomeini adalah seorang ulama yang menginterpretasikan Islam sebagai agama yang memiliki komitmen terhadap perkembangan sosial dan politik, seperti yang dituliskan oleh Shaul Bakhas, Ayatullah Khomeini "interpreted Islam as a commitment to sosial and politic causes" ${ }^{56}$ Bagi Imam Khomeini, masalah yang harus mendapatkan perhatian serius adalah perlunya Islam dan Iran merdeka dari kolonialisme Barat dan Timur, serta perlunya kaum ulama bertanggung jawab untuk kemanusiaan, tidak hanya di Iran tetapi juga terhadap orang-orang lapar dan tertindas dimanapun mereka berada. Imam Khomeini yakin bahwa Islam itu bersifat politis, kalau tidak maka agama hanyalah "omong kosong" belaka. Menurut Khomeini, "al-Qur'an memuat seratus kali lebih banyak, ayat-ayat yang berkenaan dengan masalahmasalah sosial daripada masalah-masalah ibadah.

Pemisahan agama dan politik serta adanya tuntutan bahwa ulama tidak boleh campur dalam masalahmasalah sosial politik, menurut Imam Khomeini merupakan propaganda dari Imperialisme. Ia mengecam para ulama yang enggan melibatkan diri dalam masalah-masalah sosial politik. Mereka itulah yang menurut Imam Khomeini dinilai sebagai orang-orang yang menolak kewajiban dan misi yang didelegasikan pada mereka dari para Imam. Khomeini mengutuk sikap para "ulama istana" (ulama of the court/ akhund-ha-e-darbari), yaitu mereka yang berdampingan dengan Syah dan menerima jabatan yang diberikan Syah). Para ulama seperti itu menurut Khomeini merupakan "musuh Islam". ${ }^{57}$

\footnotetext{
${ }^{55}$ Bhakas, The Reign, hlm. 21.

${ }^{56}$ Bakhas, hlm. 21 dan Sihbudi, Biografi, hlm. 108.

${ }^{57}$ Momen, An Introduction, hlm. 196.
}

\section{Gagasan "Wilayatul faqih" (Pemerintahan oleh Faqih)}

Salah satu gagasan yang paling menonjol dalam pemikiran politik Imam Khomeini adalah idenya tentang wilayatul faqih (pemerintahan para faqih) yang pada dasarnya menghendaki agar kepemimpinan pada umumnya, termasuk kepemimpinan politik, harus berada di tangan terpercaya. Pemikiran politik Imam Khomeini mengenai wilayatul faqih yang menjadi bagian terpenting dalam sistem politik Republik Islam Iran ini memberikan tekanan pada imamah yang diartikan sebagai kepemimpinan agama dan politik yang sekaligus disandang oleh faqih (ahli hukum agama).

Sebagai sebuah sistem pemerintahan yang mengamalkan hukum Tuhan dan yang mendapat pengawasan dari para ahli hukum agama (faqih), menurut pendapat Imam Khomeini, sistem Islam akan mengungguli semua sistem pemerintahan yang tidak adil di dunia ini. ${ }^{58}$ Keyakinannya yang mendalam tentang keterkaitan erat antara agama dan politik, menjadi salah satu landasan utama bagi keteguhan Imam Khomeini dalam mengembangkan struktur "Pemerintahan Islam yang dipimpin oleh para ulama". Menurutnya, negara Islam akan menjamin keadilan sosial, demokrasi yang sebenarnya dan kemerdekaan murni dari imperialisme. ${ }^{59}$ Islam dan Pemerintahan Islam adalah fenomena ilahi yang penggunaannya menjamin kebahagiaan manusia di dunia dan di akhirat. ${ }^{60}$

Seperti yang dikatakan Enayat Hamid, kontribusi paling berani imam Khomeini untuk wacana modern mengenai negara Islam adalah penegasannya bahwa esensi negara seperti itu bukanlah konstitusinya. Pada kenyataannya bukan juga komitmen penguasanya untuk mengikuti syariah, namun kualitas pemimpinnya. Khomeini beranggapan bahwa kualitas khusus ini hanya dapat dipenuhi oleh faqih. ${ }^{61}$ Khomeini, mensyaratkan setidaknya ada tiga kualitas yang harus dipenuhi oleh seorang penguasa, yaitu; kafaah, (memiliki kecerdasan dan kemampuan memerintah); 'adalah (bersifat adil yaitu sangat terpuji iman dan moralnya), dan faqahah (berpengetahuan terutama mengenai ketentuan dan aturan Islam). Jika seseorang memiliki tiga kualitas di atas yaitu mempunyai kemampuan memerintah,

\footnotetext{
${ }^{58}$ Sihbudi, “Tinjauan, hlm 161.

${ }^{59}$ Ibid., hlm.161.

${ }^{60}$ Sihbudi, Biografi, hlm. 130.

${ }^{61}$ Yamani, Filsafat, hlm. 124.
} 
mengetahui hukum dan bersikap adil, maka menurut Khomeini, orang itu akan memiliki otoritas nabi juga dan semua orang wajib mentaatinya.

Selain persyaratan faqih di atas, salah satu hal yang penting yang perlu kita ketahui dalam wilayatul faqih, otoritas dan perwakilan dari faqih adalah tugas sosial yang didelegasikan kepada mereka. Konsekuensinya, hal itu tidak menaikkan status mereka dari sisi kemanusiaan atau menurunkan status masyarakat yang mengakui perwalian dari faqih yang adil dan kapabel. Dalam buku Islam and Revolution,

Dengan otoritas kita artikan sebagai pemerintahan, administrasi sebuah negara dan Budaya hukumhukum syariah, ini merupakan sebuah tugas yang serius dan sulit, tapi tidak memberikan seseorang sebuah status yang luar biasa atau meninggalkan posisinya di atas level kemanusiaan lainnya. Dengan kata lain, otoritas di sini mempunyai arti sebagai sebuah pemerintahan, administrasi, dan pelaksanaan hukum, dan bukan seperti yang dipercayai banyak orang, sebagai sebuah previlage, tapi justru sebagai sebuah tanggung jawab berat. ${ }^{62}$

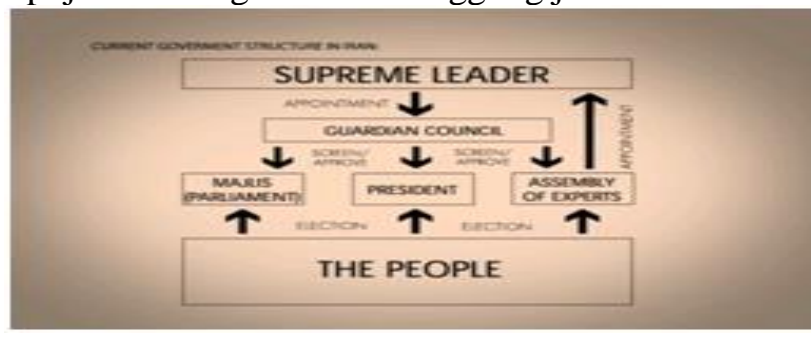

Gambar 1. Struktur Pemerintahan wilayah faqih menurut Khomeini ${ }^{63}$

\section{Bentuk Pemerintahan Republik Islam Iran}

Mengenai Bentuk Pemerintahan Iran, semenjak kemenangan revolusi Islam tahun 1979, Imam Khomeini dan para founding father Republik Islam Iran dengan penuh kesadaran memilih bentuk republik. Di satu sisi jelas ini merupakan bukti bahwa mereka tidak tertutup dari gagasan politik baru, di sisi lain ini merupakan bantahan terhadap tuduhan bahwa para tokoh revolusi Iran bermaksud menarik Iran mundur ke jaman abad pertengahan. Republik dipilih tentu saja karena bentuk pemerintahan ini dianggap bisa menjadi wadah bagi pemahaman mereka mengenai tata cara pengaturan negara modern yang sejalan dengan

62 Algar, Islam and Revolution: Writings and Declarations of Imam Khomeini, Berkeley: Mizan Press, 1981. , hlm. 62-63. struktur Islam mengenai masalah ini. ${ }^{63}$ Meskipun dalam kenyataannya ada banyak hal penting yang perlu diperhatikan.

Struktur republik, sebagaimana diterapkan dalam Republik Islam Iran, telah dimodifikasikan dengan struktur kepemimpinan wilayatul faqih, atau pemerintahan para ulama. Modifikasi ini menyentuh ketiga sendi sistem republik, meliputi institusi-institusi -eksekutif, legislatif, dan yudikatif- yang biasa disebut Trias Politika. Hal ini dirasa perlu, mengingat pada sistem ini struktur kepemimpinan Islam - apakah itu namanya wilayah atau imamah - tidak cukup terwakili di dalammya. Ada batas-batas, sebagaimana diatur menurut struktur Trias Politika, yang didalamnya kekuasaan eksekutif ditundukan oleh kekuasaan legislatif. Demikian pula kekuasaan yudikatif mempunyai batas-batasnya sendiri yang membuat mereka tidak memiliki kekuasaan yang mutlak dalam menerapkan hukum Islam. ${ }^{64}$

Dalam hal persetujuannya dengan struktur demokrasi, di mana ditunjukkan dengan istilahistilah "republik", konstitusi, parlemen dan pemilu yang ada dalam sistem pemerintahan Republik Islam saat ini bukan terletak pada kesepakatannya secara substansial mengenai makna sebagaimana dipahami Barat. Menurut Khomeini sekalipun pemerintahan ini adalah pemerintahan rakyat, tetapi sumber hukum berasal dari Tuhan. Karena itu konstitusi maupun peraturan perundangundangan haruslah mengacu kepada hukum-hukum Tuhan, yang tertera pada al-Qur'an dan Hadits serta Ijtihad ulama dalam hal ini faqih.

Menurut Imam Khomeini, negara Islam adalah negara hukum. Pemerintahan Islam adalah pemerintahan konstitusional, namun pengertian konstitusional dengan negara hukum di sini berbeda dengan apa yang selama ini dikenal. Pengertian konstitusional yang merujuk pada "hukum yang disesuaikan dengan pendapat mayoritas", tidak dikenal dalam sistem pemerintahan Islam, karena dalam pemerintahan Islam hukum sudah ada, yaitu hukum Tuhan. Dengan kata lain Tuhanlah pemegang kekuasaan legislatif-disamping sebagai pemegang kedaulatantertinggi yang sebenarnya, bukan parlemen. ${ }^{65}$

\footnotetext{
${ }^{63}$ Yamani, Filsafat Politik Islam: Antara Al-Farabi dan Khomeini (Bandung: Penerbit Mizan, 2002), hlm. 127. ${ }^{64}$ Ibid.

${ }^{65}$ Ayatullah Ruhullah Khomeini, "Sebuah Pandangan Mengenai Pemerintahan Islam" dalam Beberapa Pandangan Tentang Pemerintahan Islam, editor:
} 
Sesuai dengan tujuan dan misinya, pemerintahan memiliki tugas dan fungsi sebagai berikut: (1) mempertahankan lembaga-lembaga hukum Islam; (2) melaksanakan hukum Islam; (3) membangun kembali tatanan yang adil; (5) memungut dan memanfaatkan pajak sesuai dengan ajaran Islam; (6) menentang segala bentuk agresi, mempertahankan kemerdekaan dan integritas territorial tanah Islam; (7) memajukan pendidikan; (8) memberantas korupsi dan segala jenis penyakit sosial lainnya; (9) memberikan perlakuan yang sama terhadap semua warga negara tanpa diskriminasi; (10) memecahkan masalah kemiskinan; dan (11) memberi pelayanan kemanusiaan secara umum. ${ }^{66}$

\section{Kritik Terhadap Wilayatul faqih dalam Sistem Pemerintahan Republik Islam Iran}

Akan tetapi strktur wilayatul faqih bukannya tidak mengandung segi-segi kelemahan dan kekurangan. Salah satunya adalah mengenai persoalan kriteria faqih yang bisa diangkat menjadi pemimpin. Jelaslah sangat sulit memenuhi seorang faqih yang bisa memenuhi kreteria itu. Sementara itu, bagi para pengkritik dan pengecamnya, wilayatul faqih dipandang telah memberikan peranan yang terlalu besar kepada ulama dalam urusan kenegaraan. Sebagaimana digambarkan oleh H. E. Chehabi :

Ayatollah Shariatmadari repeatedly started his opposition to having popular sovereignty restricted. Arguing that "members of the clergy, whose role is a spiritual one, should not interfere in affairs of state", he would accept a political leadership role for the clergy only when the state passed anti-Islamic legislation, or in the event of temporary power vacuum.

Kritik keras muncul dari Bani Sadr, Presiden pertama Iran pasca revolusi 1979, yang terpilih secara meyakinkan lewat pemilu tetapi kemudian terusir. Menurut Bani Sadr, wilayatul faqih Imam Khomeini yang diterapkan di Iran hingga sekarang ini, telah memberikan peranan terlalu besar kepada ulama (para Mullah) dalam urusan kenegaraan, di mana mereka menguasai lembaga perwalian yang memiliki hak veto. Akibatnya menurut Sadr, kekuasaan sulit dikontrol dan tingkat partisipasi rakyat menjadi sangat rendah, padahal dalam sistem politik demokrasi, kontrol terhadap kekuasaan dan adanya partisipasi politik rakyat

Salim Azzam (Bandung: Penerbit Mizan, 1983), hlm. 128 dan Abd. Rahman Zainuddin dan dan M. Hamdan Basyar, Syi'ah Dan Politik Di Indonesia: Sebuah Penelitian (Bandung: Penerbit Mizan, 2000), hlm. 62.

${ }^{66}$ Ibid., hlm. 63. merupakan dua unsur yang sangat dominan. Selain itu ia juga mengkritik praktek demokrasi wilayatul faqih tersebut yang mengendalikan media, mengintimidasi orang yang menentang, membatasi dan membungkam oposisi, dan ringan tangannya para pengawal revolusi terhadap semua orang yang berbeda pendapat dengan otokrasi ulama. ${ }^{67}$

Disamping itu mulai muncul interpretasi baru terhadap wilayatul faqih, yang diantaranya dilakukan oleh Ayatullah Ni'matullah Salihi Najafabandi, dalam karyanya Vilayat-e Faqih: Hukumat-e Salihan. ${ }^{68}$ Salihi menyajikan suatu konteks baru dari doktrin wilayatul faqih di mana dia mengakui proses pemahaman masyarakat terhadap faqih tertinggi (the supreme faqih) sebagai elemen utama bagi validitas kekuasaan faqih. Dengan menyodorkan apa yang disebut sebagai konteks insha'i ("kongkret") bagi aplikasi dan Budaya doktrin wilayatul faqih, Salihi mengatakan bahwa model interpretasi sebelumnya lebih didasarkan pada konteks khabari ("abstrak") atau premis-premis yang teoritis. ${ }^{69}$

Menurut Salihi, sifat yuridis wilayah merupakan suatu "kontrak sosial" antara rakyat dan faqih yang dipercaya. Dalam rangka mendekatkan kepentingan dan peranan rakyat dengan lembaga pemegang kekuasaan hukum, ia mencoba memadukan struktur-struktur modern seperti "pemerintahan mayoritas", "kontrak sosial", dan "perwakilan", dengan prinsip-prinsip pemerintahan Islam. Salah satu wujud dari kontrak sosial itu adalah melalui bai'at antara rakyat dan pemimpin (faqih).

\footnotetext{
${ }^{67}$ Moin, "Ayatullah Khomeini Mencari Kesempurnaan: Teori dan Praktek dalam Ali Rahemna (ed), Para Perintis Zaman Baru Islam (Bandung: Penerbit Mizan, 1995), hlm 43-46

${ }^{68}$ Karya ini oleh Moussavi, diterjemahkan sebagai The Trusteeship of The Juresprudent : The Government of The Worthy dan diterbitkan di Teheran pada tahun 1984

${ }^{69}$ Moussavi, "A New Interpretation of The Theory of Vilayat-i Faqih", Middle Estern Studies, Vol. 28, No.1 (Januari 1992), hlm. 101 dan Zainuddin, Syi'ah, hlm. 64-65
} 


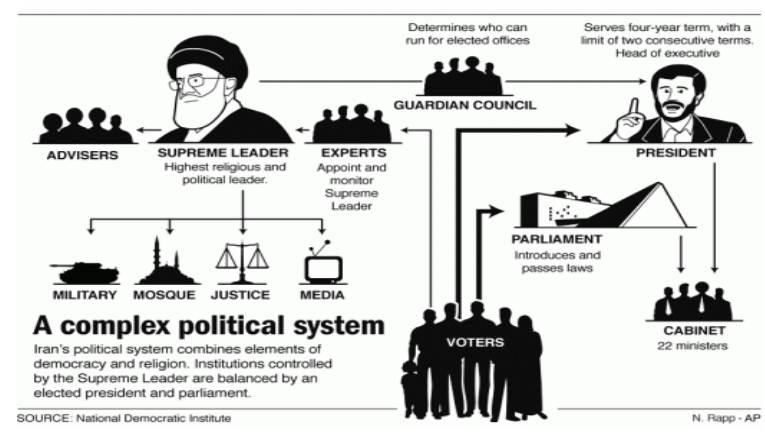

Gambar 2. Struktur Pemerintahan Republik Islam Iran menurut Ayatullah Ni'matullah Salihi Najafabandi ${ }^{70}$

Abdul Karim Sorrous dalam bukunya Menggugat Otoritas dan Tradisi Agama, ${ }^{70}$ juga mengkritik sistem pemerintahan yang berdasarkan wilayatul faqih ini. Bagi Sorrous, wilayatul faqih sangat identik dengan struktur kekuasaan absolut gereja pada abad pertengahan, dimana kekusaan politik berada di tangan segeintir orang yang mengatasnamakan gereja, sama dengan wilayatul faqih, sistem teokrasi absolut ala gereja pada abad pertengahan juga mempunyai otoritas keagamaan dan sekaligus otoritas politik dengan justifikasijustifikasi agama. Bagi Sorrous, yang juga merupakan seorang cendekiawan muslim "liberal" Iran Kontemporer, pemerintahan di Iran yang didominasi ulama saat ini kurang memiliki basis teoritis. $^{71}$

Kritik-kritik yang datang dari para penentang terhadap wilayatul faqih kebanyakan menganggap bahwa kunci utama wilayatul faqih terlalu menjustifikasikan keutamaan para wali untuk memerintah berdasarkan pengetahuan mereka. Para pengkritik ini meragukan kredibilitas dan pengetahuan religius ini, tidak cukup untuk meyakinkan bahwa kekuasaan harus dipercayakan kepada seorang faqih untuk melindungi dan memajukan kesejahteraan publik. Bagaimana kita bisa mengetahui bahwa wali tidak mementingkan urusan sendiri daripada kepentingan publik? Apakah ada suatu sistem pengawasan terhadap mereka untuk mencegah mereka menyalahgunakan otoritasnya? Kelemahan sistem ini adalah kenyataan bahwa rakyat tidak mendelegasikan otoritas pada wali, mereka tidak akan bisa secara hukum atau secara konstitusional mencabut kekuasaanpolitik dari wali. konsekuensinya para wali itu bebas dari kontrol rakyat.

\footnotetext{
${ }^{70}$ Soroush, Menggugat Otoritas dan Tradisi Agama, terj. Abdullah Ali, (Bandung: Penerbit Mizan, 2002)

${ }^{71}$ Ibid.
}

\section{KESIMPULAN DAN SARAN}

Pemerintahan Republik Islam Iran tidak bisa dilepaskan dari peranan besar Ayatullah Imam Khomeini, seorang ulama pemimpin spiritual, sekaligus pemimpin politik yang sangat dihormati di Iran. Imam Khomeini merupakan salah seorang tokoh yang paling penting di balik terjadinya revolusi Iran dan lahirnya negara Republik Islam Iran. Karena peranannya dalam memimpin revolusi Iran itulah, Imam Khomeini diangkat sebagai Rahbar (pemimpin) revolusi Islam, sebagaimana yang tercantum dalam konstitusi Iran yang disahkan Desember 1979.

Salah satu gagasan yang paling menonjol dalam pemikiran politik Imam Khomeini adalah idenya tentang Wilayatul Faqih (pemerintahan para faqih) yang pada dasarnya menghendaki agar kepemimpinan pada umumnya, termasuk kepemimpinan politik, harus berada di tangan terpercaya. Pemikiran politik Imam Khomeini mengenai Wilayatul Faqih yang menjadi bagian terpenting dalam struktur politik Republik Islam Iran ini memberikan tekanan pada imamah yang diartikan sebagai kepemimpinan agama dan politik yang sekaligus disandang oleh faqih.

Wilayatul faqih ini merupakan kelanjutan dari doktrin imamah dalam teori politik Syi'ah khususnya Syi'ah Imamiyah. Struktur ini bukan merupakan gagasan yang baru dalam pemikiran kalangan Syi'ah. Imam Khomeini yang kemudian mengembangkan dan mempraktikkan Wilayatul faqih ini ke dalam sistem pemerintahan Iran Modern.

Dalam mengaplikasikan gagasannya, Imam Khomeini berhasil menggabungkan struktur pemerintahan agama dengan pranata-pranata demokrasi. Akan tetapi Imam Khomeini memiliki definisi demokrasi yang berbeda dengan demokrasi murni dan demokrasi liberal. Menurutnya kebebasan demokrasi harus dibatasi dan kebebasan yang diberikan itu harus dilaksanakan di dalam batas-batas hukum Islam. Meskipun demikian dapat dikatakan bahwa konsep wilayatul faqih merupakan salah satu varian dari demokrasi. Dalam konsep ini mekanisme keseimbangan dan kesejajaran (check and balance) harus berjalan, meskipun lembaga tersebut berkedudukan di bawah otoritas wali faqih. Menurut Imam Khomeini tanpa pengawasan dari wilayatul faqih, pemerintah akan menjadi despotik. Jika pemerintahan itu tidak sesuai dengan kehendak 
Tuhan dan jika Presiden dipilih tanpa arahan seorang faqih, maka pemerintahan itu tidak sah.

Sistem pemerintahan Republik Islam Iran dapat diklasifikasikan ke dalam sistem demokrasi yang religius, apapun istilah yang diberikan; baik istilah "Teo-Demokrasi" Maududi, "Theistic Demokrasi" Moh. Natsir "Islamo-Demokrasi" Nurcholis Madjid, Demokrasi Islam atau apapun yang dilabelkan padanya pada dasarnya adalah sama. Sebagai konsekuensi logis, Implikasi dari struktur demokrasi Islam gagasan Khomeini ini merupakan model dan bentuk pemerintahan alternatif yang dapat menjadi acuan bagi negara-negara Muslim lainnya di masa mendatang.

Kajian-kajian tentang struktur yang mengawinkan antara Islam dan demokrasi yang kemudian menghasilkan penilaian sejauh mana demokrasi bergandengan dengan paradigma Islam perlu untuk terus dikembangkan, dengan harapan kajian seperti ini pada gilirannya dapat memperkuat proses demokrasi di Indonesia untuk terus mengarah kepada nilai-nilai Islam, mengingat Islam bukan hanya perlu diperjuangkan tetapi lebih dari itu harus disemaikan, ditanam, dipupuk dan dibesarkan melalui upaya-upaya terencana, teratur dan terarah pada seluruh lapisan masyarakat. Islam baik struktur politik maupun nilai-nilai keagamaan, tidak bisa diwariskan begitu saja, melainkan juga harus diajarkan, disosialisasikan, dan diaktualisasikan, khususnya bagi generasi muda.

\section{DAFTAR PUSTAKA}

[1] Ali Qaderi, Sayyed. 2001. The Life of Imam Khomeini, Volume One, M. J. Khalili and Salar Manaf Anari (ed) (The Institute for Compilation and Publication df Imam Khomeini's Work: International Affair Department, Teheran).

[2] Algar, Hamid. 1996. "Iman Khomeini Sang Sufi", dalam Mata Air Kecemerlangan:Sebuah Pengantar Untuk Memahami Pemikiran Imam Khomeini. Bandung : Penerbit Mizan.

[3] Apter, David E. 1985. Pengantar Analisa Politik. Jakarta : LP3ES.

[4] Azzam, Salim. 1983. (ed) Ayatullah Ruhullah Khomeini, "Sebuah Pandangan Mengenai Pemerintahan Islam" dalam Beberapa Pandangan Tentang Pemerintahan Islam. Bandung : Penerbit Mizan.
[5] Bakhas, Shahul. 1985. The Reign of The Ayatullohs. London : I.B. Taurish \& Co. Ltd.

[6] Basri, Safiq. 1987. Iran Pasca Revolusi, Sebuah Reportase Perjalanan. Jakarta : Pustaka Sinar Harapan.

[7] Beker et.al, Anthony. 1990. Metode Penelitian Filsafat. Yogyakarta : Kanisius.

[8] Budiardjo, Miriam. 2003. Dasar-Dasar Ilmu Politik. Jakarta : Penerbit GramediaPustaka Utama.

[9] Couloumbis, Theodore A. dan Wolfe, James H. 1990. Alih bahasa Marcedes Marbun, Pengantar Hubungan Internasional Keadilan dan Power.

[10] Dahl, Robert A. 1992. Demokrasi dan Para Pengkritiknya. Jakarta : Yayasan Obor Indonesia. Dalam buku mereka. 1999. Demokrasi di Negara-negara muslim: problem dan prospek. Jakarta : Mizan.

[11] Enayat, Hamid. 1988. Reaksi Politik Sunni dan Syi'ah, Pemikiran Islam Modern Menghadapi Abad 20. Bandung : Pustaka.

[12] Esposito, John L. 1990. Islam dan Politik, terj. Jusup Soe'yb. Jakarta : Bulan Bintang.

[13] Al-Khawarizmi, Khalifatullah. 2009. Iran Versus Amerika Serikat. Jakarta : TP.

[14] Fauzi Heryadi, Ammar. 2005. "Catatan Kaki Untuk Pemimpin Ideal: Dalam Filsafat Politik Plato dan Imam Khomeini" dalam Islam Alternatif: Jurnal Kajian Keislaman Himpunan Pelajar Indonesia - Iran, HPI (Himpunan Pelajar Indonesia-Iran), Divisi Media dan Penerbitan, Vol.1, No.1, Summer.

[15] Fandi, Behroz Kamal, Duta Besar Republik Islam Iran, Pikiran dan Pandangan Politik Imam Khomeini, makalah Seminar Nasional akhir tahun, "Iran, Islam, dan Barat", yang dilaksanakan pada tanggal 23 Desember 2006, Yogyakarta

[16] Haydar, Hamid. 2001. "Filsafat Politik Imam Khomeini" dalam Jurnal Al Huda, Vol II, No. 4, Tahun 2001.

[17] Irfan, Abdul Hakim. 1988. Nadriyat alWilāyat al-Faqih: Dirāsat wa Tahlīl wa Naqd. Darul Imar.

[18] Islamic Government ini merupakan terjemahan dari buku aslinya yang menggunakan bahasa Persia dengan judul Hukumat-i Islami, di terjemahkan juga secara lengkap dalam bahasa Perancis, Urdu, Arab dan Turki. Kemudian diterjemahkan lagi kedalam bahasa Indonesia oleh Muhammad Anis Maulachela, "Sistem Pemerintahan Islam" dan diterbitkan oleh Pustaka Zahra, tahun 2002. 
[19] Kamil, Sukron. 2002. Islam dan Demokrasi: Telaah Strukturtual dan Historis.Jakarta : Gaya Media Pratama.

[20] Khomeini, Imam. 1981. Islam and Revolution: Writing and Declarations of Imam Khomeini (Trans. Hamid Algar), Berkeley : Mizan Press.

[21] Lapidus, Ira M. 1999. Sejarah Sosial Umat Islam, Bagian 3, terj. Ghufron A. Mas'adi. Jakarta : Raja Grafindo Persada.

[22] Maududi, Abul A'la. 1990. Hukum dan Konstitusi Struktur Politik Islam, terj. Asep Hikmat dari The Islamic Law and Government. Bandung : Mizan.

[23] Moin, Baqer. 1996. "Ayatullah Khomeini Mencari Kesempurnaan: Teori dan Realitas" dalam Ali Rahnema (ed), Para Perintis Zaman Baru Islam. Bandung : Penerbit Mizan.

[24] Mottahedeh, Roy P. 2001. entri "Wilayah alFaqih" dalam Jhon L Esposito (ed), Ensiklopedi Oxford Dunia Islam Modern Jilid VI, terj. Eva YN. Bandung : Penerbit Mizan.

[25] Moussawi, Ahmad. 1993. "Teori Wilayat Faqih: Asal Mula dan Penampilannya dalam Literatur Hukum Syi'ah," dalam MasalahMasalah Teori Politik Islam (ed. Mumtaz Ahmad). Bandung : Penerbit Mizan.

[26] Mudzhar, M. Atho. 1998. Membaca Gelombang Ijtihad: Antara Tradisi dan Liberalisasi. Yogyakarta : Titian Ilahi Press.

[27] Muharam Habsyie, Ibrahim. 2005. "Wilayatul faqih: Kalam atau Fiqih?" dalam Islam Alternatif: Jurnal Kajian Keislaman Himpunan Pelajar Indonesia Iran, HPI (Himpunan Pelajar IndonesiaIran), (Divisi Media dan Penerbitan,Vol.1, No.1, Summer, 2005)
[28] Prayogo, Imam dan Tobroni. 2003. Metodologi Penelitian Sosial dan Agama. Bandung : Rosda Karya.

[29] Qassem, Naim. 2005. Blueprint Hizbullah. Terj. Ruslani. Jakarta : Cahaya Insan Suci. Sihbudi, Riza. 1989. Dinamika Revolusi Islam Iran, dari Jatuhnya Syah hingga Wafatnya Ayatullah Khomeini. Jakarta : Pustaka Hidayah.

[30] Sihbudi, Riza. 1991. "Politik Parlemen dan Oposisi di Iran Paca Revolusi " dalam Jurnal Ilmu Politik Vol. 11. Jakarta.

[31] Sihbudi, Riza. 1996. Biografi Politik Imam Khomeini. Jakarta : Gramedia Pustaka Utama dan ISMES.

[32] Sihbudi, Riza. 2004. "Tinjauan Teoritis dan Praktis Atas Struktur Vilayat-I-Faqih : Sebuah Studi Pengantar ", dalam Asep Gunawan (ed), Artikulasi Islam Kultural. Jakarta : PT. Raja Grafindo Persada.

[33] Sihbudi, Riza. 2007. Menyandera Timur Tengah. Jakarta : Mizan Publika.

[34] Soroush, Abdul Karim. Menggungat Otoritas dan Tradisi Agama, terj. Abdullah Ali. Bandung : Penerbit Mizan.

[35] Syahab, Ali. 2006. Agama Politik : Nalar Politik Islam, Penerbit Citra.

[36] Taheri, Amir. 1985. The Spirit of Allah: Khomeini and The Islamic Revolution. London: Hutnehinson.

[37] Vaezi, Ahmed. 2001. Syi'ah Islamic Thought London, England : ICAS (Islamic College for Advance Studies).

[38] Yamani. 2002. Filsafat Politik Islam: Antara Al-Farabi dan Khomeini. Bandung: Penerbit Mizan.

[39] Zainuddin, Abd. Rahman dan Basyar, M. Hamdan. 2000. Syi'ah Dan Politik Di Indonesia: Sebuah Penelitian. Bandung : Penerbit Mizan. 